\title{
Transition Metals in Freshwater Crustaceans, Tilapia, and Inland Water: Hazardous to the Population of the Small Island Province
}

\author{
Christine Joy M. Agarin ${ }^{1,2,3}$, Doreen R. Mascareñas ${ }^{3,4}$, Ronnel Nolos ${ }^{3,5}$ (D) Eduardo Chan $^{6}$ \\ and Delia B. Senoro $1,3,7, *(\mathbb{D}$
}

1 School of Graduate Studies, Mapua University, Manila 1002, Philippines; christinejoyagarin@gmail.com 2 School of Chemical, Biological, Materials Engineering and Sciences, Mapua University, Manila 1002, Philippines 3 Yuchengco Innovation Center, Mapua University, Manila 1002, Philippines; doreen.mascarenas@g.msuiit.edu.ph (D.R.M.); ronnelnolos@gmail.com (R.N.)

4 School of Agriculture, Marinduque State College, Torrijos, Marinduque 4903, Philippines

5 Mapua-MSC Joint Research Laboratory, Marinduque State College, Boac, Marinduque 4900, Philippines

6 Dyson College of Arts and Sciences, Pace University, New York, NY 10038, USA; echan@pace.edu

7 School of Civil, Environmental, and Geological Engineering, Mapua University, Manila 1002, Philippines

* Correspondence: dbsenoro@mapua.edu.ph; Tel.: +63-2-8251-6622

check for updates

Citation: Agarin, C.J.M.; Mascareñas, D.R.; Nolos, R.; Chan, E.; Senoro, D.B. Transition Metals in Freshwater Crustaceans, Tilapia, and Inland Water: Hazardous to the Population of the Small Island Province. Toxics 2021, 9, 71. https:// doi.org/10.3390/toxics 9040071

Academic Editors: Octavio Pérez Luzardo and Katrin Vorkamp

Received: 4 February 2021

Accepted: 24 March 2021

Published: 01 April 2021

Publisher's Note: MDPI stays neutral with regard to jurisdictional claims in published maps and institutional affiliations.

Copyright: (C) 2021 by the authors Licensee MDPI, Basel, Switzerland. This article is an open access article distributed under the terms and conditions of the Creative Commons Attribution (CC BY) license (https:/ / creativecommons.org/licenses/by/ $4.0 /)$.

\begin{abstract}
This paper elaborates on the potential toxicants detected in inland water, freshwater crustaceans, and tilapia in an island that experienced mining disasters in 1993 and 1996. Specimen samples were collected in six municipalities of the island province in 2019 and presence of metals $(\mathrm{Cd}, \mathrm{Cr}, \mathrm{Cu}, \mathrm{Fe}, \mathrm{Mn}, \mathrm{Ni}, \mathrm{Pb}$, and $\mathrm{Zn}$ ) were analyzed using Inductively Coupled Plasma-Optical Emission Spectrometer (ICP-OES). Potential ecological risks analysis followed the Hakanson approach. Canonical correspondence analysis PAST Version 3.22, IBM SPSS 25.0, and Pearson correlation were employed for statistical analysis, and GIS Pro 2.5 for mapping of sampling locations and spatial distribution. Results showed that Mn and Zn concentration was highest in surface water (SW) and groundwater (GW), respectively. All metal concentration values exceeded the maximum permissible limit by regulatory international organizations. Elevated concentration of $\mathrm{Cr}, \mathrm{Cu}, \mathrm{Fe}, \mathrm{Mn}$, and $\mathrm{Zn}$ was detected in both crustaceans and tilapia. The calculated health hazard indices were greater than one, which means potential high adverse effects on public health when ingested. The municipality of Sta. Cruz and Torrijos recorded higher potential ecological risk among the six municipalities. Results of the correlation analysis suggested that metals in SW and GW have a similar origin, mutual dependence, and identical behavior during transport.
\end{abstract}

Keywords: fishes; inland water; metals; risks; island; spatial distribution; toxicants

\section{Introduction}

The province of Marinduque is a small island in the Philippines located at $13.4767^{\circ} \mathrm{N}$, $121.9032^{\circ}$ E. It has a land area of $959.25 \mathrm{~km}^{2}$, is about $170 \mathrm{~km}$ south of Metro Manila, and has six municipalities, namely, Boac (B), Buenavista (BV), Gasan (G), Mogpog (M), Torrijos (T), and Sta. Cruz (S), and 218 barangays. Barangays are the smallest territorial, administrative and local level of government unit. Marinduque has a population of 234,521 and its longest river is approximately $27 \mathrm{~km}$, recorded to have the largest copper reserves in the country [1], and one of the world's largest copper mines during the period of 19691996 [2]. This contributed to the local economy of the island. The activities engaged in open pit mining in the municipality of Boac and Sta. Cruz in the early 1970s started at the portion of Mt. Tapian, Boac ore deposit. The mine wastes from Tapian pit were discharged to Calancan Bay, Sta. Cruz through a drainage tunnel. When the ore deposits at Mt. Tapian were depleted in late 80s, the mining operation moved to Maguilaguila, Sta. Cruz in 1990. This new site is about three kilometers north of Tapian with its own tailings/siltation pond 
impounded by an earth dam. The depleted Tapian open pit was used as temporary storage of mine wastes from Maguilaguila. On 6 December 1993, the Maguilaguila siltation dam collapsed and mine tailings flux was hosted by Mogpog River. Riverside barangays were flooded with mine tailings. On 24 March 1996, i.e., two years and three months after the Maguilaguila mining disaster event, Tapian dam failed and the $27 \mathrm{~km}$ long, Boac River was flooded with mine tailings [3]. Mogpog and Boac are adjacent municipalities. Mining activities were halted in 1997 leaving two abandoned mine pits. One pit has an opening of two kilometers long. The loss of riverine habitat, including the substantial increase in the magnitude of flood events after the two disaster events were associated with, according to the local population, the 1993 and 1996 mining disaster events [1].

Mine tailings contain pyrite (iron sulfide) or chalcopyrite (copper-iron sulfide). Sulfidic mine tailings are prone to produce acid mine drainage, which has been reported to cause adverse effects to the environment, aquatic life, and public health [4]. Further, open pit mining exposes the subsurface walls to moisture and the atmospheric oxygen speeds up the oxidation process by anaerobic bacteria (Thiobacillus ferrooxidans). In addition, the open pit stores water during heavy precipitation or typhoon, which increases the rate of oxidation by a factor of one million [5]. The iron sulfides in aquatic environment are hazardous and classified as an acute hazard, Category 1, H400 by the European Union REACH (Registration, Evaluation, Authorization and Restriction of Chemicals) under the CLP Regulation (EC) No. 1272/2008. The oxidation process acidifies the environment and mobilizes metals such as lead ( $\mathrm{Pb})$, arsenic (As), cadmium (Cd), and among other metals. Exposed rocks or subsurface walls of open mine pits produce acid rock drainage and are regarded as autocatalytic due to feedback process, which is difficult to control [5]. Metals released and mobilized by the technological activities of humans tend to persist indefinitely, circulating and accumulating throughout the food chain.

At the right concentration, many metals are essential to life. However, in excess or elevated concentration, same metals can be considered toxicants. Toxic heavy metals residues in the environment, if not controlled and managed well, can be hazardous to the public. Food chains are affected when mining disaster happens; hence, other countries require screening of chemicals in fish and fishery products [6], especially if fishes and crustaceans are part of the population's diet. However, regular screening of metals in fish and other agricultural products has not been a regular practice and not part of a regulation in the Philippines. According to Baby et al. [7], heavy metals become toxic if not metabolized by the body and accumulate in the soft tissues. The low-level chronic exposure to heavy metals not metabolized and discharge by the body become a public health problem.

There were various studies focusing on river and coastal water quality, sediments, and human health in Marinduque [8-12] and neighboring countries [13-16]. However, there was very limited study on metal detection in freshwater crustaceans and tilapia (fish) and the spatial distribution of the potential ecological risks (PER) posed by these freshwater fish together with inland water quality. Hence, this study focused on understanding the inland and freshwater tilapia and crustacean's quality, and the potential risks when ingested by the population. Information on the spatial distribution of metals pollution and its ecological risks is helpful in the local and national government in making relevant strategies, programs, and policies to protect the environment and the public.

\section{Materials and Methods}

\subsection{Study Area and Sample Collection}

Commercially available freshwater crustaceans (Macrobrachium sp.) and tilapia (Oreochromis niloticus and Channa striata) were bought from local fishermen. Surface water (SW) and groundwater (GW) samples were collected across the Marinduque island (Figure 1). Marinduque, Philippines is a tropical and warm island with an annual mean temperature of $27^{\circ} \mathrm{C}$. The island province sets on volcanic, igneous, and sedimentary rocks. These media are porous and groundwater can flow through porous media. There is no 
pronounced wet and dry season in the island as precipitation is experienced throughout the year. Criteria for selection of freshwater fishes and crustaceans were based on what was most often eaten by people living on the island. The collected samples were packed in a polyethylene container, sealed, labeled, and stored in a cooler at approximately $4{ }^{\circ} \mathrm{C}$ before transferring to the laboratory for treatment and analysis. The SW and GW samples were collected in accordance with the U.S. EPA Number SESDPROC-201-R4 and U.S. EPA and SESDPROC-301-R4 protocol for SW and GW sampling, respectively. The source of water for fishponds are normally from shallow wells. Crustaceans were collected from rivers and streams. Size of crustaceans was considered during collection to acquire sufficient mass after drying for analysis.

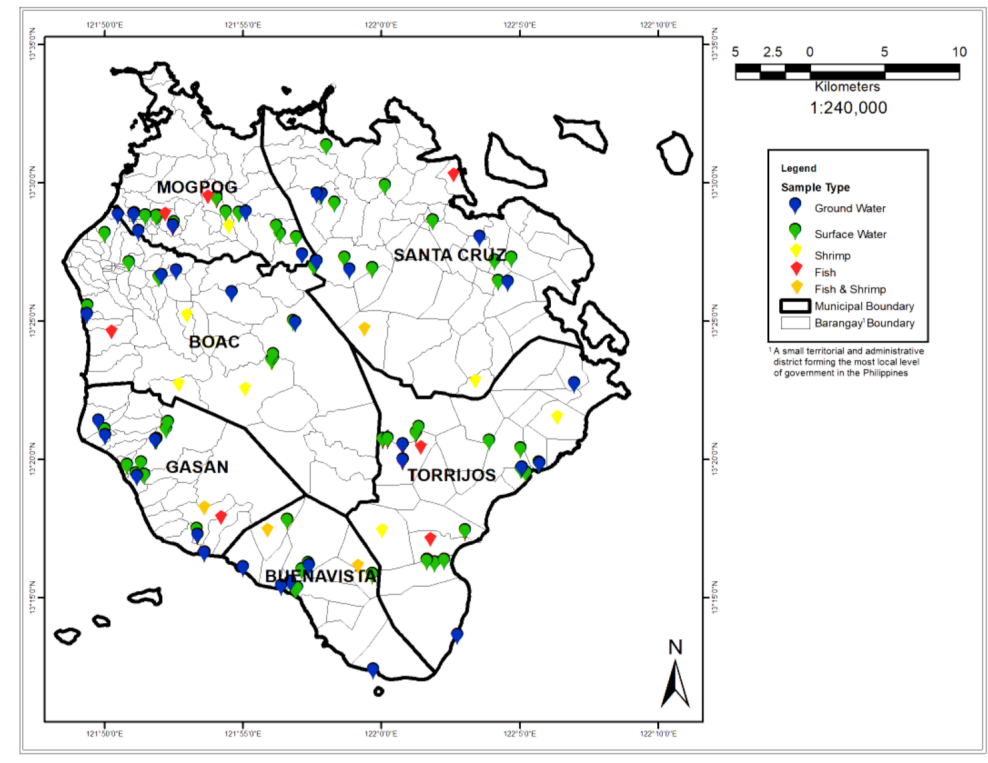

Figure 1. Map of the study area and location of sampling points.

\subsection{Sample Preparation for Heavy Metal Analysis}

Twenty four (24) tilapia and crustaceans, sixty-two (62) and thirty-five (35) samples of SW and GW, respectively, were collected in 2019 at various locations described in Figure 1. Crustaceans and tilapia were collected in 11 and 13 different places in Marinduque, respectively. The samples were cut into about $0.5 \mathrm{~cm}$ pieces and dried at MSC-Mapua joint research laboratory at Boac, Marinduque using a dehydrator at $68{ }^{\circ} \mathrm{C}$ for $7-8 \mathrm{~h}$. A total of 121 samples were analyzed in triplicates for the presence of eight transition and post-transition metals such as cadmium $(\mathrm{Cd})$, chromium $(\mathrm{Cr})$, copper $(\mathrm{Cu})$, iron $(\mathrm{Fe})$, lead $(\mathrm{Pb})$, manganese $(\mathrm{Mn})$, nickel (Ni), and zinc $(\mathrm{Zn})$ using Inductively Coupled Plasma Optical Emission Spectrometer (ICP-OES) Perkin Elmer Optima 8000 with minimum $\mathrm{R}^{2}=0.9995$ per metal. The digestion and analysis were in accordance with U.S. EPA Method 200.3/200.11 and U.S. EPA Method 3005A/200.7 for tilapia and crustaceans' tissues and inland water samples, respectively. The analysis was carried out at the Wet Laboratory of Yuchengco Innovation Center of Mapua University in Manila, Philippines.

\subsection{Potential Ecological Risk Determination}

The data collected from ICP-OES were used to calculate the pERI following the Håkanson's sedimentological approach [17]. This requires four hypotheses to determine the potential ecological risk index ( $p E R I)$ such as: (a) concentration-pERI increases as concentration increases; (b) number of pollutants-the pERI increases as the number of target metals increases; (c) toxic factor-pERI shall be graded; and (d) sensitivity-various 
inland waters have different sensitivity to toxic substance. Based on these hypotheses, this study used Equations (1) and (2), as shown below.

$$
\begin{gathered}
C_{d}=\sum_{i=1}^{8} C_{f}^{i}=\sum_{i=1}^{8} \frac{C_{0}^{i}}{C_{n}^{i}} \\
p E R I=\sum_{i=1}^{8} E_{r}^{i}=\sum_{i=1}^{8} T_{r}^{i} \cdot C_{f}^{i}
\end{gathered}
$$

where, $C_{d}$ is the degree of contamination or the concentration of the metal (i); $C_{f}^{i}$ is the contamination factor of metal; $C_{0}^{i}$ is the mean concentration of the metal in water, tilapia, and crustaceans; $C_{n}^{i}$ is the standard pre-industrial reference concentration level; $p E R I$ is the potential ecological risk index of water, tilapia, and crustaceans, which is the sum of $E_{r}^{i}$. The $E_{r}^{i}$ is the potential ecological risk factor for metal; and $T_{r}^{i}$ is the toxic-response factor/coefficient for metals, i.e., $\mathrm{Cd}=30, \mathrm{Cr}=2, \mathrm{Cu}=5, \mathrm{~Pb}=5$, and $\mathrm{Zn}=1$ [17]. The PER represents the sensitivity of a biological community to toxic substances caused by the pollution/contamination, which can be used as a diagnostic tool for water pollution control. This pERI determination approach categorized the contamination factor and degree of contamination into four groups as shown in Table 1 . While values for background reference $\left(C_{n}^{i}\right)$ and toxicity coefficients $\left(T_{r}^{i}\right)$ of metals, shown in Table 2 , necessary in calculating the $\left(C_{f}^{i}\right)$ and $E_{r}^{i}$, respectively. The PER is expressed in terms of a comprehensive pERI, which is the sum of all $\left(E_{r}^{i}\right)$ s. The total PER includes the determination of the carcinogenicity of the metals to human when ingested, as illustrated in Equations (3)-(7).

Table 1. Gradation (critical) range for contamination factor, degree of contamination, risk coefficient, and index [17].

\begin{tabular}{lcccc}
\hline \multicolumn{1}{c}{ Potential Ecological Risks (PER) } & $C_{f}^{i}$ & $C_{\boldsymbol{d}}$ & $E_{r}^{i}$ & Ecological Risk Index (ERI) \\
\hline Low & $C_{f}^{i}<1$ & $C_{d}<8$ & $E_{r}^{i}<40$ & $E R I<150$ \\
Moderate & $1 \leq C_{f}^{i}<3$ & $8 \leq C_{d}<16$ & $40 \leq E_{r}^{i}<80$ & $150 \leq E R I<300$ \\
Considerable & $3 \leq C_{f}^{i}<6$ & $16 \leq C_{d}<32$ & $80 \leq E_{r}^{i}<160$ & $300 \leq E R I<600$ \\
Potentially high & - & - & $160 \leq E_{r}^{i}<320$ & - \\
Very high & $C_{f}^{i} \geq 6$ & $C_{d} \geq 32$ & $E_{r}^{i} \geq 320$ & $E R I \geq 600$ \\
\hline
\end{tabular}

Table 2. Background reference values $C_{n}^{i}$ and $T_{r}^{i}$ [17].

\begin{tabular}{ccc}
\hline Heavy Metal & $C_{n}^{i}, \mathbf{m g ~} \mathbf{k g}-{ }^{1}$ & $\mathbf{T}_{r}^{i}$ \\
\hline Cadmium $(\mathrm{Cd})$ & 1 & 30 \\
Chromium $(\mathrm{Cr})$ & 90 & 2 \\
Copper $(\mathrm{Cu})$ & 50 & 5 \\
Lead $(\mathrm{Pb})$ & 70 & 5 \\
Zinc $(\mathrm{Zn})$ & 175 & 1 \\
\hline
\end{tabular}

The potential human health risk (pHHR) index from the consumption of tilapia, crustaceans, and ingestion of water were estimated by calculating the estimated daily intake (EDI), target hazard quotient (THQ), and carcinogenicity risk (CR) all in accordance with the U.S. EPA $[18,19]$. The level of exposure through ingestion/oral route of a particular heavy metal in tilapia/crustaceans and water were expressed by calculating the EDI using Equations (3) and (4), respectively.

$$
\begin{gathered}
E D I=\frac{C_{m} \cdot E_{f} \cdot E_{d} \cdot I R \cdot C F}{B W \cdot A T_{n}} \times 10^{-3} \\
E D I=\frac{C_{m} \cdot E_{f} \cdot E_{d} \cdot I R}{B W \cdot A T_{n}}
\end{gathered}
$$


where $C_{m}$ is the concentration of the metals in the samples $\left(\mathrm{mg} \mathrm{kg}^{-1}\right.$ or $\left.\mathrm{mg} \mathrm{L}^{-1}\right)$; IR is the ingestion rate $\left(\mathrm{g} \mathrm{day}^{-1}\right.$ or L day $\left.{ }^{-1}\right) ; E_{f}$ is exposure frequency $\left(365 \mathrm{~d} \mathrm{yr}^{-1}\right) ; E_{d}$ is the exposure in years; $B W$ is the average adult body weight $(\mathrm{kg}) ; A T_{n}$ is the averaging time; $C F$ is the conversion factor.

The THQ, used to investigate the risk of non-carcinogenic effects, is the ratio between the EDI and the oral reference dose $\left[\mathrm{RfD}_{\mathrm{o}},\left(\mathrm{mg} \mathrm{kg}^{-1} \text { day }^{-1}\right)^{-1}\right]$, and was calculated using Equation (5) $[18,20,21]$.

$$
T H Q=\frac{E D I}{R f D_{o}}
$$

Since exposure to two or more pollutants may result in additive and/or interactive effects, cumulative health risk, or the health hazard index (HHI), can be evaluated by summing the individual metal target hazard quotient values and was calculated using Equation (6) [20-22].

$$
H H I=T H Q_{(\text {toxicant } 1)}+T H Q_{(\text {toxicant } 2)}+\ldots+T H Q_{(\text {toxicant } n)}
$$

When the calculated THQ/HHI value is $<1$, adverse health effects to the concerned receptors are not likely to occur. If $\mathrm{THQ} / \mathrm{HHI}=1$, non-carcinogenic health risk is likely. However, should THQ/HHI >1, the metal concentration exceeds the reference concentration [18]. The ingestion dose in this consideration was assumed to be equal to the absorbed contaminant dose considering that cooking has no effect on the concentrations of metals.

Carcinogenic risk assessment evaluates the likelihood of an individual developing cancer due to exposure to the potential carcinogen over a lifetime [23]. Equation (7) [18] was used for the estimation of the cancer risk (CR) using the carcinogenicity potency factor [or cancer slope factor, CSF, $\left(\mathrm{mg} \mathrm{kg}^{-1} \text { day }^{-1}\right)^{-1}$ ] and the EDI from equation for tilapia and crustaceans and Equation (4) for SW and GW.

$$
C R=C S F \cdot E D I
$$

\subsection{Statistical Analysis and Spatial Distribution}

Canonical correspondence analysis (CCA) was employed using PAST Version 3.22 software to determine the relationship of the PERs with HHRs. This was coupled with the IBM SPSS Statistics Version 25.0 and Pearson correlation coefficient analysis. After which, GIS Pro Version 2.5 was employed to plot the sampling locations and mapped the spatial distribution of metal concentration in water and the potential ecological risks (PER) across the island province.

\section{Results}

Subsections below elaborate on the toxicants detected from freshwater crustaceans (Macrobrachium sp.), tilapia (O. niloticus and C. striata), and SW and GW. It further illustrates the spatial distribution of these toxicants and its potential ecological risk as well as its trend.

\subsection{Concentration of Metals in Surface Water and Groundwater}

The SW samples had concentrations of $\mathrm{Cd}(0-0.032), \mathrm{Cr}(0-0.016), \mathrm{Cu}(0-2.454), \mathrm{Fe}$ (0.005-0.846), $\mathrm{Pb}(0-0.032), \mathrm{Mn}(0.014-2.450), \mathrm{Ni}(0-0.043)$, and $\mathrm{Zn}(0-1.651) \mathrm{mgL}^{-1}$. Metal concentrations in GW ranged from Cd (0.001-0.099), $\mathrm{Cr}(0.017-0.113), \mathrm{Cu}(0.001-0.121)$, $\mathrm{Fe}(0.482-10.70), \mathrm{Pb}(0.002-0.117)$, Mn (0.098-1.483), Ni (0.001-0.118), and Zn (0.11810.63) $\mathrm{mg} \mathrm{L}^{-1}$. Table 3 shows the average concentrations of heavy metals in the water samples, highlighting the limits set by World Health Organization (WHO) [24] and Philippine National Standard for Drinking Water (PNSDW) [25]. The concentrations in SW and GW of $\mathrm{Cd}\left(0.009\right.$ and $\left.0.030 \mathrm{mg} \mathrm{L}^{-1}\right), \mathrm{Pb}\left(0.011\right.$ and $\left.0.042 \mathrm{mg} \mathrm{L}^{-1}\right)$, and $\mathrm{Mn}(0.608$ and $0.585 \mathrm{mg} \mathrm{L}^{-1}$ ) respectively, exceeded the maximum permissible limit (MPL) prescribed by both international and national regulatory bodies [24,25]. Likewise, $\mathrm{Cr}\left(0.051 \mathrm{mg} \mathrm{L}^{-1}\right)$ and $\mathrm{Zn}\left(3.163 \mathrm{mg} \mathrm{L}^{-1}\right)$ levels in GW samples both exceeded the MPL. Concentrations of $\mathrm{Cr}$ and $\mathrm{Zn}$ in $\mathrm{SW}, \mathrm{Cu}, \mathrm{Fe}$, and $\mathrm{Ni}$ in both SW and GW were below MPL. Concentration 
of six (6) among the eight (8) metals ( $\mathrm{Cd}, \mathrm{Cr}, \mathrm{Fe}, \mathrm{Pb}, \mathrm{Mn}$, and $\mathrm{Zn}$ ) exceeded the PNSDW limits in the GW of Torrijos, while five (5) did so in Sta. Cruz. The distribution trend of metal concentration in water is shown in Table 4. It illustrates that Mn had the highest concentration in SW while $\mathrm{Zn}$ in GW all across municipalities.

Table 3. Average concentration of metals in water samples $\left(\mathrm{mg} \mathrm{L}^{-1}\right)$ with maximum permissible limit (MPL).

\begin{tabular}{|c|c|c|c|c|c|c|c|c|c|}
\hline \multirow{2}{*}{ Location } & \multirow{2}{*}{ Water Sample } & \multicolumn{8}{|c|}{ Metal } \\
\hline & & $\mathrm{Cd}$ & $\mathrm{Cr}$ & $\mathrm{Cu}$ & $\mathrm{Fe}$ & $\mathbf{P b}$ & Mn & $\mathbf{N i}$ & $\mathrm{Zn}$ \\
\hline \multirow{2}{*}{ Boac } & SW & 0.009 & 0.005 & 0.076 & 0.094 & 0.009 & 0.029 & 0.012 & 0.016 \\
\hline & GW & 0.001 & 0.034 & 0.034 & 1.233 & 0.010 & 1.483 & 0.001 & 0.118 \\
\hline \multirow{2}{*}{ Buenavista } & SW & - & - & - & 0.005 & - & 0.014 & - & - \\
\hline & GW & 0.001 & 0.017 & 0.001 & 0.482 & 0.002 & 0.098 & 0.001 & 0.385 \\
\hline \multirow{2}{*}{ Gasan } & SW & 0.013 & 0.007 & 0.059 & 0.204 & 0.012 & 0.093 & 0.012 & 0.062 \\
\hline & GW & 0.001 & 0.018 & 0.121 & 0.750 & 0.002 & 0.304 & 0.001 & 1.600 \\
\hline \multirow{2}{*}{ Mogpog } & SW & - & - & 0.717 & 0.127 & - & 0.765 & 0.002 & 0.082 \\
\hline & GW & 0.001 & 0.042 & 0.075 & 10.70 & 0.027 & 0.363 & 0.001 & 10.63 \\
\hline \multirow{2}{*}{ Torrijos } & SW & 0.002 & 0.002 & 0.115 & 0.355 & 0.011 & 0.299 & 0.006 & 0.067 \\
\hline & GW & 0.099 & 0.113 & 0.115 & 2.565 & 0.117 & 0.479 & 0.118 & 5.011 \\
\hline \multirow{3}{*}{ Sta. Cruz } & SW & 0.032 & 0.016 & 2.454 & 0.846 & 0.032 & 2.450 & 0.043 & 1.651 \\
\hline & GW & 0.079 & 0.081 & 0.113 & 0.691 & 0.093 & 0.783 & 0.094 & 1.240 \\
\hline & SW & \pm 0.018 & +0.010 & \pm 2.530 & \pm 0.597 & \pm 0.017 & \pm 2.070 & \pm 0.026 & \pm 1.404 \\
\hline \multirow[t]{3}{*}{$S D$} & GW & \pm 0.045 & \pm 0.041 & \pm 0.058 & \pm 9.375 & \pm 0.051 & \pm 1.532 & \pm 0.053 & \pm 10.428 \\
\hline & IO [24] & 0.003 & 0.050 & 2.000 & 3.000 & 0.010 & 0.050 & 0.070 & 3.000 \\
\hline & DW [25] & 0.003 & 0.050 & 1.000 & 1.000 & 0.010 & 0.400 & 0.070 & 5.000 \\
\hline
\end{tabular}

Note: GW—groundwater; SW—surface water; SD—Standard Deviation; WHO—World Health Organization; PNSDW—Philippine

National Standards for Drinking Water. Bold numbers are limits set by WHO and PNSDW per metal.

Table 4. Trend of metal concentration accumulation in water across the island.

\begin{tabular}{lcc}
\hline & Location & Water Sample \\
\cline { 2 - 3 } & SW & $\mathrm{GW}$ \\
\hline Boac & $\mathrm{Mn}>\mathrm{Cu}>\mathrm{Zn}>\mathrm{Fe}>\mathrm{Cd}>\mathrm{Pb}>\mathrm{Cr}>\mathrm{Ni}$ & $\mathrm{Zn}>\mathrm{Fe}>\mathrm{Mn}>\mathrm{Cu}>\mathrm{Cr}>\mathrm{Pb}>\mathrm{Cd}>\mathrm{Ni}$ \\
Buenavista & $\mathrm{Mn}>\mathrm{Fe}$ & $\mathrm{Zn}>\mathrm{Fe}>\mathrm{Mn}>\mathrm{Cd}>\mathrm{Cr}>\mathrm{Ni}>\mathrm{Cu}>\mathrm{Pb}$ \\
Gasan & $\mathrm{Mn}>\mathrm{Cu}>\mathrm{Zn}>\mathrm{Fe}>\mathrm{Ni}>\mathrm{Cd}>\mathrm{Pb}>\mathrm{Cr}$ & $\mathrm{Zn}>\mathrm{Cu}>\mathrm{Fe}>\mathrm{Mn}>\mathrm{Cr}>\mathrm{Ni}>\mathrm{Cd}>\mathrm{Pb}$ \\
Mogpog & $\mathrm{Mn}>\mathrm{Cu}>\mathrm{Zn}>\mathrm{Fe}>\mathrm{Ni}$ & $\mathrm{Zn}>\mathrm{Fe}>\mathrm{Mn}>\mathrm{Cu}>\mathrm{Pb}>\mathrm{Cr}>\mathrm{Ni}>\mathrm{Cd}$ \\
Torrijos & $\mathrm{Mn}>\mathrm{Fe}>\mathrm{Cu}>\mathrm{Zn}>\mathrm{Pb}>\mathrm{Ni}>\mathrm{Cd}>\mathrm{Cr}$ & $\mathrm{Zn}>\mathrm{Fe}>\mathrm{Mn}>\mathrm{Cr}>\mathrm{Cu}>\mathrm{Ni}>\mathrm{Pb}>\mathrm{Cd}$ \\
Sta. Cruz & $\mathrm{Mn}>\mathrm{Zn}>\mathrm{Cu}>\mathrm{Fe}>\mathrm{Ni}>\mathrm{Pb}>\mathrm{Cd}>\mathrm{Cr}$ & $\mathrm{Zn}>\mathrm{Fe}>\mathrm{Mn}>\mathrm{Cr}>\mathrm{Cu}>\mathrm{Ni}>\mathrm{Pb}>\mathrm{Cd}$ \\
\hline
\end{tabular}

\subsection{Heavy Metals Concentrations in Crustaceans and Tilapia}

Figure 2 illustrates the spatial concentration distribution of these eight metals in SW with tilapia and crustaceans. The concentrations of the heavy metals in crustaceans (M. lar, M. placidulum) and tilapia (O. niloticus and C. striata) in wet weight (w.w.) are enumerated in Table 5. Recorded values for the six municipalities are shown in Figure 3. The red horizontal line represents the maximum permissible limit set by the international regulatory bodies $[18,26-28]$. The metals concentrations in crustaceans and tilapia recorded the following: $\mathrm{Cr}=44.61-79.42, \mathrm{Cu}=53.39-4898, \mathrm{Fe}=1344-1.129 \times 10^{4}, \mathrm{Mn}=53.33-5731$, and $\mathrm{Zn}=1266-6362$ in dry weight (d.w.) basis, respectively. Concentrations of $\mathrm{Cd}, \mathrm{Ni}$, and $\mathrm{Pb}$ were below the instrument detection limits; hence, were reported as non-detected (ND) analytes. The average concentration of $\mathrm{Zn}$ was 562.2 and $963.8 \mathrm{mg} \mathrm{kg}^{-1}$ w.w. in tilapia and crustaceans, respectively. The $\mathrm{Cu}$ in crustaceans $\left(770.2 \mathrm{mg} \mathrm{kg}^{-1}\right.$ w.w.) exceeded the MPL set by international regulatory bodies (highlighted numbers). 
Table 5. Concentrations of toxic metals in crustaceans and tilapia ( $\mathrm{mg} \mathrm{kg}^{-1}$ w.w.) with MPL.

\begin{tabular}{|c|c|c|c|c|c|c|c|c|}
\hline \multirow{2}{*}{ Biota } & \multicolumn{8}{|c|}{ Metal } \\
\hline & $\mathrm{Cd}$ & $\mathrm{Cr}$ & $\mathrm{Cu}$ & $\mathrm{Fe}$ & $\mathbf{P b}$ & Mn & $\mathrm{Ni}$ & $\mathrm{Zn}$ \\
\hline Tilapia & ND & 13.59 & 17.72 & 438.8 & ND & 121.1 & ND & 562.2 \\
\hline $\mathrm{SD}$ & - & \pm 3.19 & \pm 10.17 & +174.1 & - & \pm 157.1 & - & \pm 315.4 \\
\hline Crustaceans & ND & 12.74 & 770.2 & 1172 & ND & 603.5 & ND & 963.8 \\
\hline SD & - & \pm 3.64 & \pm 239.9 & \pm 788.9 & - & \pm 602.6 & - & \pm 271.7 \\
\hline FAO [26] & 0.500 & - & 30.00 & - & 0.500 & - & - & 40.00 \\
\hline WHO [27] & 1.000 & 50.00 & 30.00 & 100 & 2.000 & 1 & $0.500-1.000$ & 100.0 \\
\hline $\begin{array}{l}\text { USEPA } \\
{[18]}\end{array}$ & 2.000 & 8.000 & 120.0 & - & 4.000 & - & - & 120.0 \\
\hline EC [28] & 0.050 & - & - & - & 0.300 & - & - & 120.0 \\
\hline
\end{tabular}

Note: SD—Standard Deviation; FAO—Food and Agricultural Organization; WHO-World Health Organization; US EPA—United States Environmental Protection Agency; EC-European Commission. Bold numbers are concentration limits set by FAO, WHO, USEPA, and EC.

\subsection{Human Health Risk of Heavy Metals by Ingestion}

The EDI of metals through crustaceans and tilapia by the population in Marinduque is presented in Table 6 . The crustaceans contributed more than tilapia to the population EDI as illustrated in Figure 4. The metals of concern in freshwater crustaceans and tilapia were $\mathrm{Cu}, \mathrm{Fe}, \mathrm{Mn}$, and $\mathrm{Zn}$.

Table 6. The estimated daily intake (EDI) of metals $\left(\mathrm{mg} \mathrm{kg}^{-1} \mathrm{day}^{-1}\right)$ through crustaceans and tilapia.

\begin{tabular}{|c|c|c|c|c|c|c|c|c|c|}
\hline \multirow{2}{*}{ Location } & \multirow{2}{*}{ Biota } & \multicolumn{8}{|c|}{ Metal } \\
\hline & & $\mathrm{Cd}$ & $\mathrm{Cr}$ & $\mathrm{Cu}$ & $\mathrm{Fe}$ & $\mathrm{Pb}$ & Mn & $\mathbf{N i}$ & $\mathrm{Zn}$ \\
\hline \multirow{2}{*}{ Boac } & Tilapia & - & 0.023 & 0.026 & 0.462 & - & 0.165 & - & 0.724 \\
\hline & Crustaceans & - & 0.022 & 1.479 & 1.508 & - & 1.730 & - & 1.266 \\
\hline \multirow{2}{*}{ Buenavista } & Tilapia & - & 0.024 & 0.030 & 0.826 & - & 0.173 & - & 1.382 \\
\hline & Crustaceans & - & 0.015 & 1.206 & 1.057 & - & 0.448 & - & 1.381 \\
\hline \multirow{2}{*}{ Gasan } & Tilapia & - & 0.017 & 0.043 & 0.555 & - & 0.028 & - & 0.588 \\
\hline & Crustaceans & - & 0.015 & 0.876 & 1.310 & - & 0.685 & - & 1.127 \\
\hline \multirow{2}{*}{ Mogpog } & Tilapia & - & 0.013 & 0.016 & 0.406 & - & 0.016 & - & 0.382 \\
\hline & Crustaceans & - & 0.020 & 1.055 & 0.824 & - & 1.039 & - & 1.372 \\
\hline \multirow{2}{*}{ Torrijos } & Tilapia & - & 0.023 & 0.019 & 0.824 & - & 0.221 & - & 1.130 \\
\hline & Crustaceans & - & 0.019 & 0.887 & 2.006 & - & 0.274 & - & 1.247 \\
\hline \multirow{2}{*}{ Sta. Cruz } & Tilapia & - & 0.017 & 0.019 & 0.713 & - & 0.441 & - & 0.644 \\
\hline & Crustaceans & - & 0.019 & 1.141 & 3.409 & - & 1.030 & - & 1.921 \\
\hline
\end{tabular}

The computed EDI range for the SW and GW samples were Cd $\left(2.308 \times 10^{-5}-4.138 \times 10^{-3}\right)$, $\mathrm{Cr}\left(7.184 \times 10^{-5}-4.714 \times 10^{-3}\right), \mathrm{Cu}\left(3.617 \times 10^{-5}-1.022 \times 10^{-1}\right), \mathrm{Fe}\left(2.082 \times 10^{-4}-4.459 \times\right.$ $\left.10^{-1}\right), \mathrm{Pb}\left(1.674 \times 10^{-5}-4.868 \times 10^{-3}\right), \mathrm{Mn}\left(5.671 \times 10^{-4}-1.021 \times 10^{-1}\right), \mathrm{Ni}\left(3.846 \times 10^{-5}\right.$ $\left.4.901 \times 10^{-3}\right)$, and $\mathrm{Zn}\left(1.157 \times 10^{-5}-4.427 \times 10^{-1}\right)$. The SW and GW contributions to the human mean daily intake of the heavy metals revealed that SW contributed $\mathrm{Cu}$ and $\mathrm{Mn}$ concentrations more than the GW; however, the later contributed more Fe and Zn.

The potential health hazard of the toxicants was interpreted based on the values of the THQ and HHI. Table 7 shows the calculated potential HHI of the heavy metals found in crustaceans, tilapia, SW, and GW. Ingestion of the SW and GW samples recorded to have THQ values ranged from $2.308 \times 10^{-2}-4.138 \times 10^{0} \mathrm{Cd}, 4.789 \times 10^{-5}-3.143 \times 10^{-3}$ $\mathrm{Cr}, 6.144 \times 10^{-2}-2.556 \times 10^{0} \mathrm{Cu}, 2.975 \times 10^{-4}-6.370 \times 10^{-1} \mathrm{Fe}, 4.186 \times 10^{-3}-1.217 \times 10^{0}$ $\mathrm{Pb}, 4.051 \times 10^{-3}-7.292 \times 10^{-1} \mathrm{Mn}, 1.641 \times 10^{-3}-2.451 \times 10^{-1} \mathrm{Ni}$, and $3.858 \times 10^{-5}$ $1.476 \times 10^{0} \mathrm{Zn}$. The HHI values for SW and GW in Mogpog $\left(1.001 \times 10^{0}\right.$ and $2.607 \times 10^{0}$, respectively) and in Sta. Cruz $\left(5.341 \times 10^{0}\right.$ and $5.013 \times 10^{0}$, respectively) were greater than 
1. Further, GW samples from Torrijos had HHI value of $6.714 \times 10^{0}$, which was way above

1. The HHI values greater than 1 pose a potential high health risk to human population.

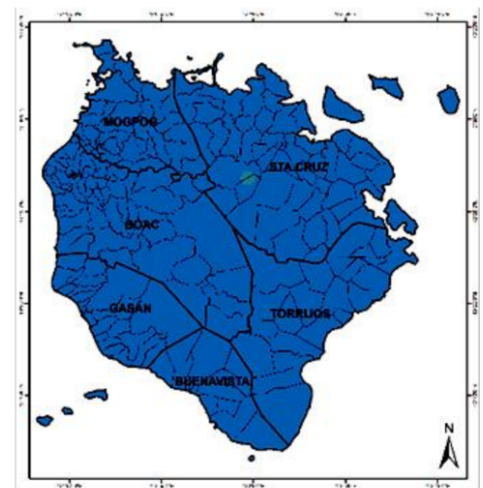

(a)

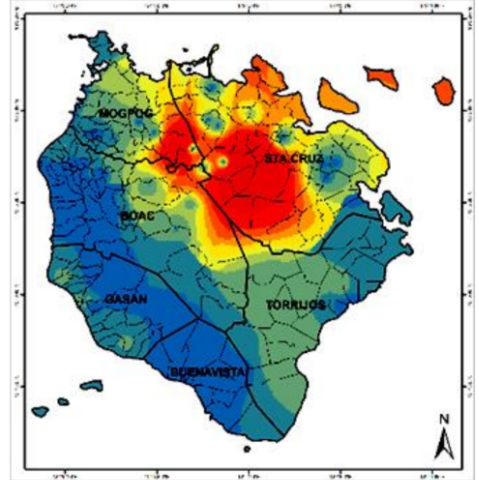

(c)

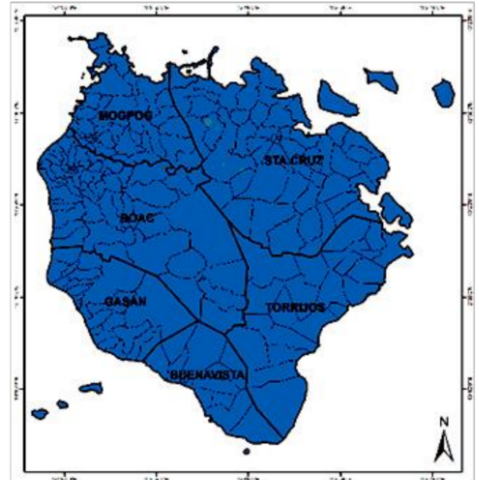

(e)

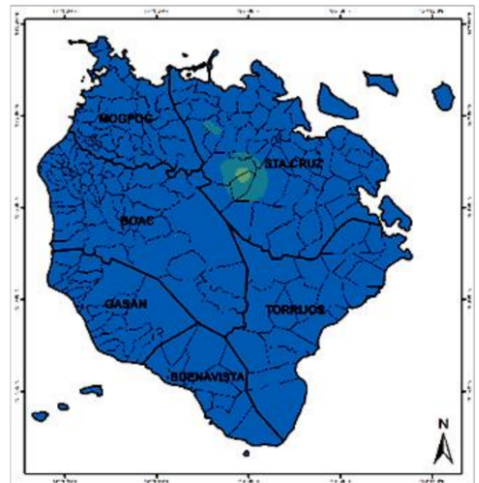

(g)

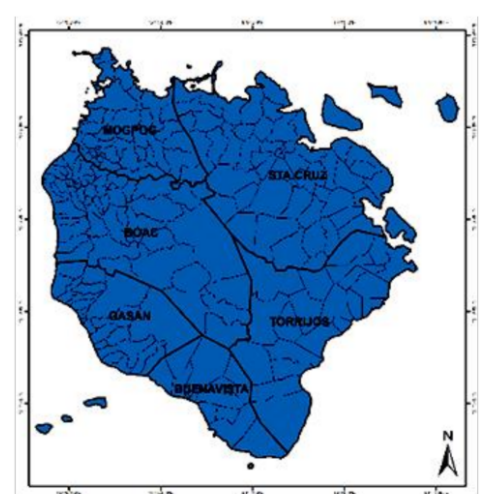

(b)

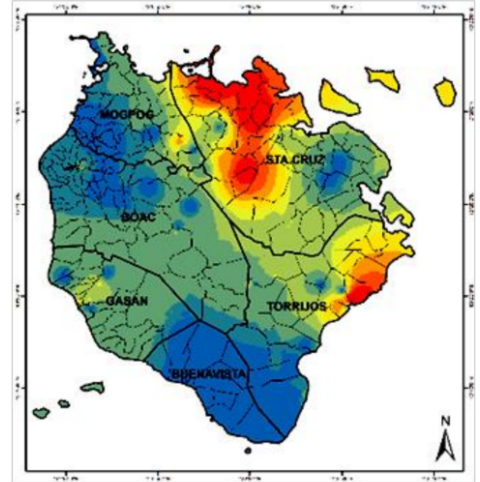

(d)

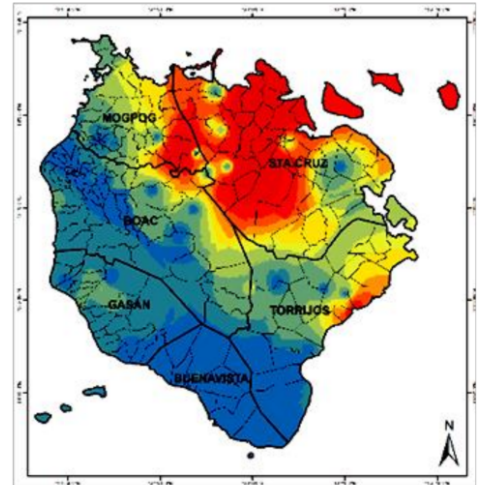

(f)

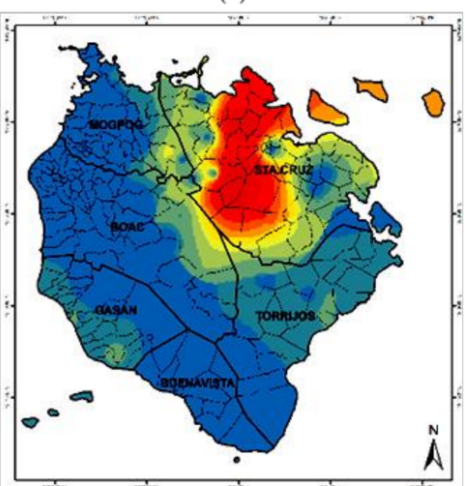

(h)

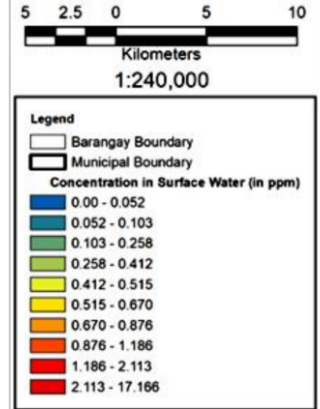

$1.186 \cdot 2.113$
$2.113 \cdot 17.160$

Figure 2. Surface water spatial distribution of metals concentrations in Marinduque: (a) $\mathrm{Cd},(\mathbf{b}) \mathrm{Cr}$, (c) $\mathrm{Cu},(\mathbf{d}) \mathrm{Fe},(\mathbf{e}) \mathrm{Pb}$, (f) $\mathrm{Mn},(\mathbf{g}) \mathrm{Ni}$, and (h) $\mathrm{Zn}$. 


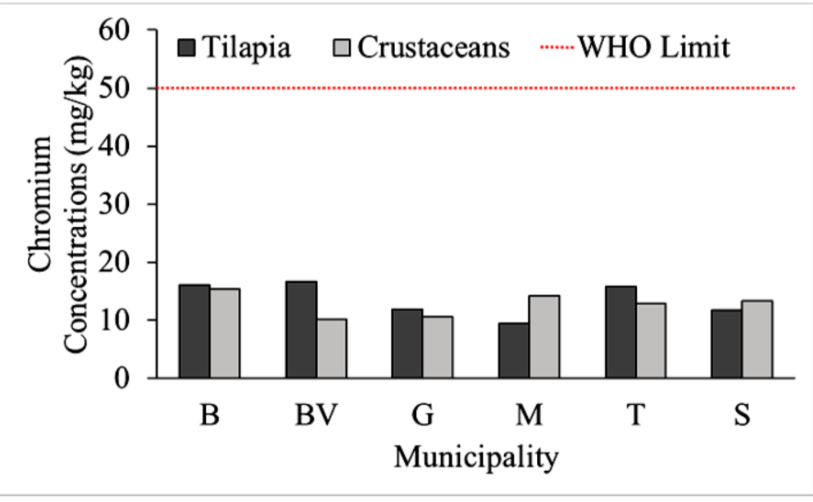

(a)

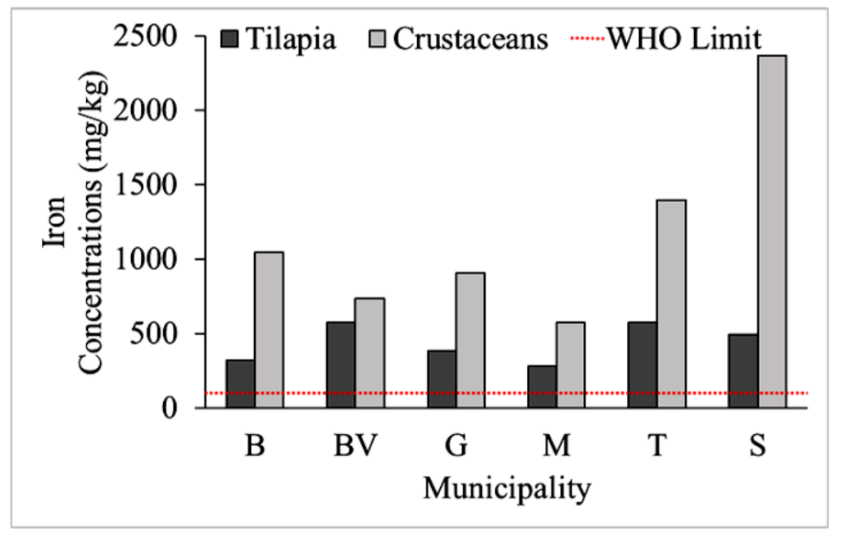

(c)

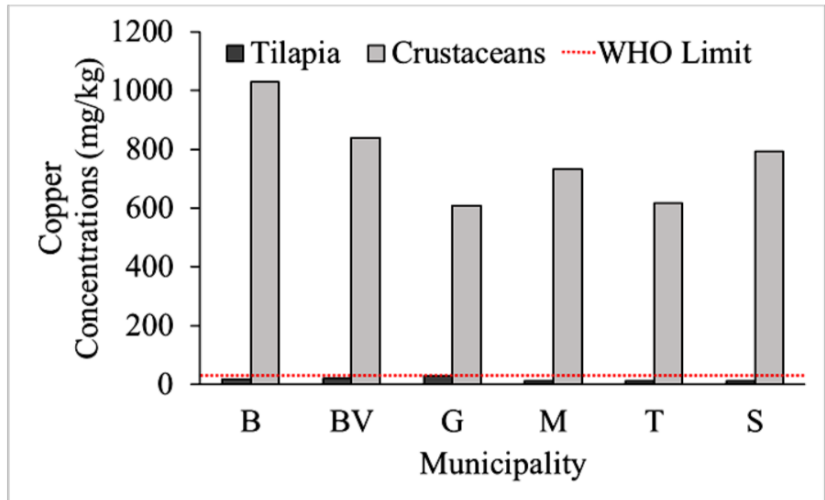

(b)

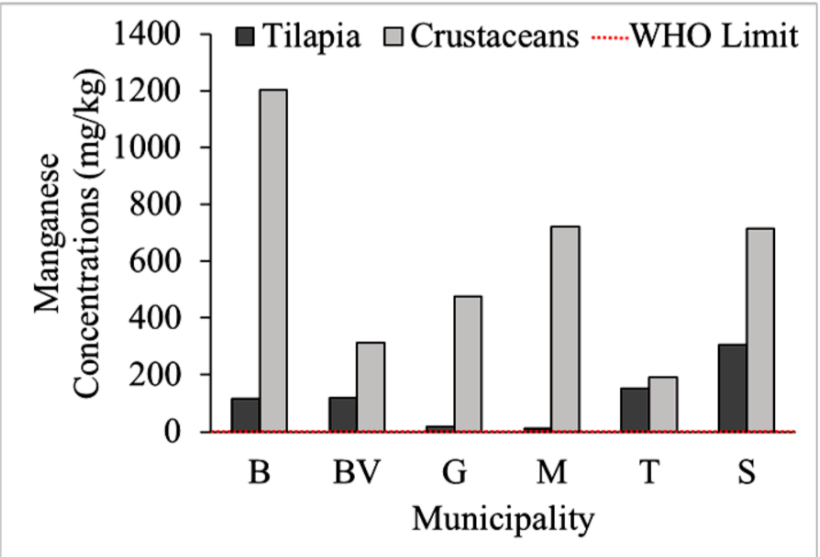

(d)

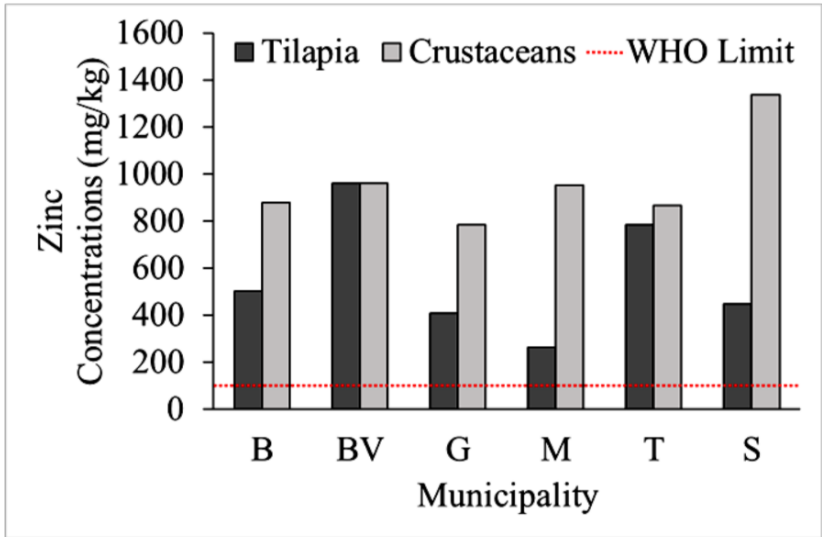

(e)

Figure 3. The concentrations of tilapia and crustaceans per municipality of the island province. Note: The red horizontal line represents the maximum permissible limit (MPL) set by WHO. The vertical bars are the concentration of metals in tilapia and crustaceans. The concentration of $\mathrm{Cr}$ (a) in both tilapia and crustaceans was below MPL. The concentration of $\mathrm{Cu}$ in crustaceans (b) was beyond the WHO MPL However, the Cu concentration in tilapia was below WHO MPL. The Fe concentration (c) in both tilapia and crustaceans was beyond MPL in all six municipalities. The Mn concentration (d) in both tilapia and crustaceans was beyond WHO MPL. Mn concentration in crustaceans collected from Gasan and Mogpog recorded the lowest concentration among the six municipalities. The municipality of Boac recorded the highest Mn concentration in crustaceans. The Zn concentration (e) in both tilapia and crustaceans was beyond the MPL in all six municipalities. Sta. Cruz municipality recorded the highest concentration in the island province for iron and zinc. Boac municipality recorded the highest concentration for copper and manganese. 


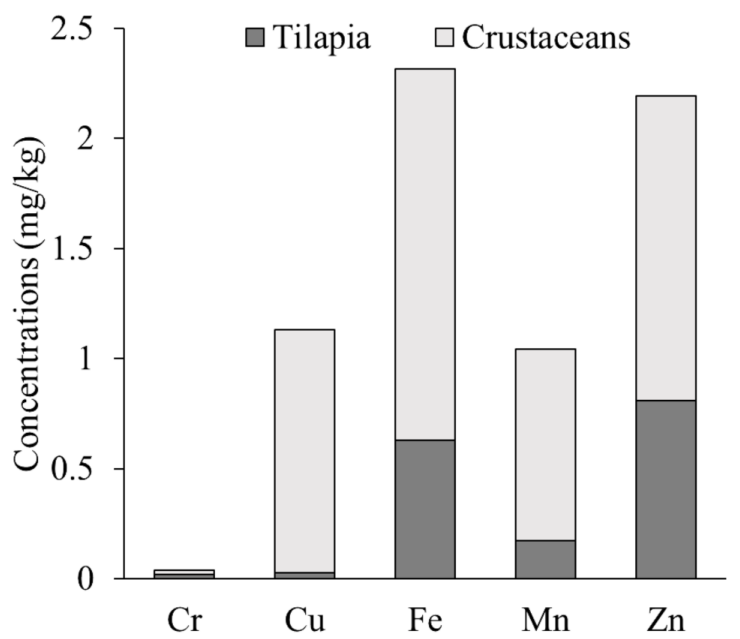

Figure 4. Contribution of crustaceans and tilapia to the mean EDI.

Table 7. Potential health hazard index (HHI) by ingestion of aquatic resources from Marinduque.

\begin{tabular}{lcccc}
\hline \multirow{2}{*}{ Location } & \multicolumn{3}{c}{ HHI } \\
\cline { 2 - 5 } & Crustaceans & Tilapia & SW & GW \\
\hline Boac & 55.73 & 4.920 & $6.027 \times 10^{-1}$ & $6.921 \times 10^{-1}$ \\
Buenavista & 39.48 & 7.784 & $4.387 \times 10^{-3}$ & $1.576 \times 10^{-1}$ \\
Gasan & 32.43 & 4.040 & $7.880 \times 10^{-1}$ & $5.262 \times 10^{-1}$ \\
Mogpog & 39.55 & 2.381 & $1.001 \times 10^{0}$ & $2.607 \times 10^{0}$ \\
Torrijos & 31.18 & 7.005 & $4.504 \times 10^{-1}$ & $6.714 \times 10^{0}$ \\
Sta. Cruz & 47.17 & 6.806 & $5.341 \times 10^{0}$ & $5.013 \times 10^{0}$ \\
\hline
\end{tabular}

Consumption of crustaceans and tilapia on a daily basis of $87.1 \mathrm{~g}$ leads to a potential accumulation of $0.009-0.016 \mathrm{Cr}, 0.403-36.98 \mathrm{Cu}, 0.580-4.870 \mathrm{Fe}, 0.115-12.36 \mathrm{Mn}$, and 1.264-6.403 Zn. Fish and crustacean species have HHI > 1. Summing up the THQs of the targeted metals pointed to an adverse health effects of the exposed population. It was recorded that the HHI values for tilapia (2.381-7.784) were much lower than the HHI values for the crustaceans (31.18-55.73). This means the ingestion of crustaceans was more hazardous than tilapia.

The likelihood of the concerned receptors developing cancer due to $\mathrm{Cr}, \mathrm{Cd}, \mathrm{Ni}$, and $\mathrm{Pb}$ exposure (metals are carcinogenic) was evaluated using EDI and CSF to carry out CRA. This evaluation was carried out based on the results of HHI that recorded greater than one. It showed that the average population life time cancer risk associated with crustaceans and tilapia consumption (0.007-0.012) and ingestion of SW and GW $\left(1.423 \times 10^{-7}-2.607 \times 10^{-2}\right)$ would result to approximately 1 case per 100,000 population. As per the U.S. Environmental Protection Agency [16], the value of $10^{-5}$ is an acceptable lifetime carcinogenic risk. However, it should be noted that the PER of the island for metals in crustaceans and tilapia was high. Hence, the cumulative effects of trace metals may lead to chronic poisoning as a result of long-term exposure.

\subsection{The Cumulative Potential Ecological Risks (PER)}

The pERI at municipal level is illustrated by Figure 5 with areas in blue with the highest pERI. Tilapia, SW, and GW had pERI values lower than 150, which means low potential ecological risk. The $\mathrm{pERI}$ by crustaceans and tilapia in six municipalities recorded a range of $0.991-1.765 \mathrm{Cr}$ and $7.233-36.36 \mathrm{Zn}$. This is less than forty (40), which means low potential ecological risk. Also, the pERI of $\mathrm{Cu}$ by tilapia recorded 5.339-14.28, which indicated low PER. However, pERI of Cu by crustaceans for Gasan and Torrijos recorded 290.1 and 293.0, respectively which means considerable risk. Whereas, the pERI Cu for 
Boac (498.8), Buenavista (399.5), Mogpog (349.3), and Sta. Cruz (377.9), which means high potential risk. The pERI of $\mathrm{Cu}$ by crustaceans collected from Gasan and Torrijos were greater than 160, which means considerable risk. While, the pERI of $\mathrm{Cu}$ collected from the other four municipalities exceeded three hundred (300), which means high potential ecological risk. The calculated pERI for the heavy metals found in crustaceans, tilapia, SW, and GW were tabulated in Table 8. The cumulative pERI, which is the summation of coefficients $E_{r}^{i}$, is low for tilapia (13.56-37.81), SW $\left(1.587 \times 10^{-6}-1.230 \times 10^{0}\right)$, and GW $\left(1.941 \times 10^{-2}\right.$ $\left.3.030 \times 10^{0}\right)$. Cumulative pERI for crustaceans (312.5-515.4) was considerable. Elevated concentration of $\mathrm{Cr}, \mathrm{Cu}$ ad $\mathrm{Zn}$ was common in crustaceans and tilapia.

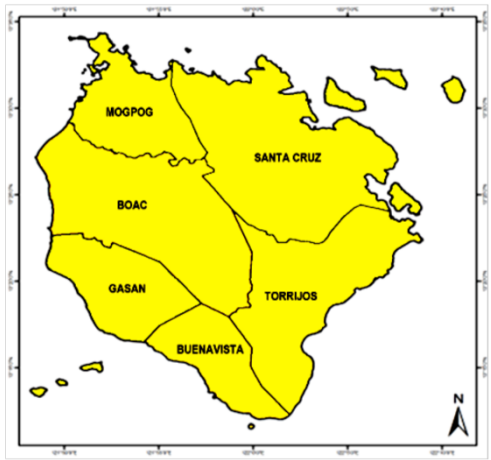

(a)

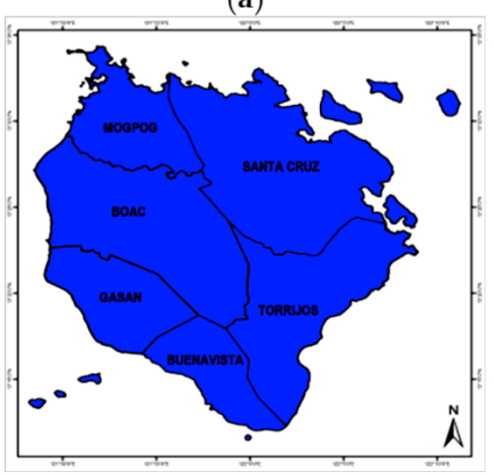

(c)
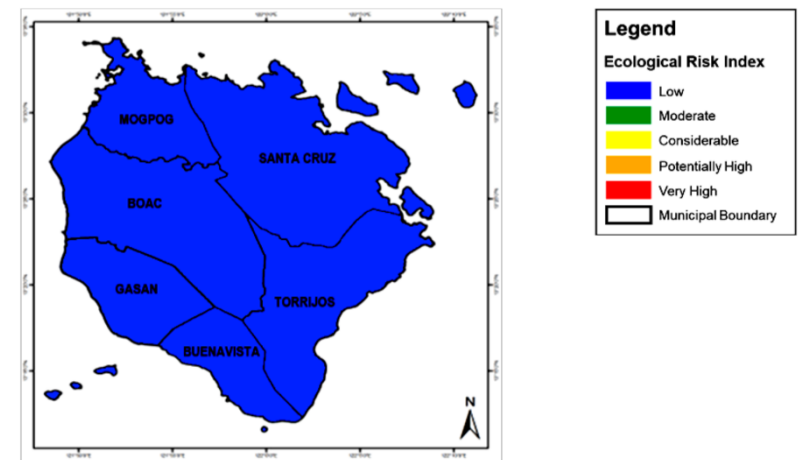

(b)

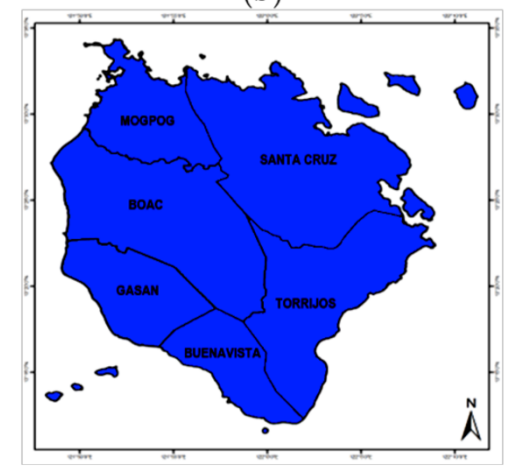

(d)

Figure 5. The spatial distribution of pERI at municipal level by the elevated metals concentration in (a) surface water, (b) groundwater, (c) crustaceans, and (d) tilapia.

Table 8. The potential ecological risk index $(\mathrm{p} E R I)$ in aquatic resources from Marinduque.

\begin{tabular}{lcccc}
\hline \multirow{2}{*}{ Location } & \multicolumn{3}{c}{ pERI } \\
\cline { 2 - 5 } & Crustaceans & Tilapia & SW & GW \\
\hline Boac & 515.4 & 24.03 & $2.889 \times 10^{-1}$ & $2.217 \times 10^{-2}$ \\
Buenavista & 426.7 & 37.81 & $1.587 \times 10^{-6}$ & $1.941 \times 10^{-2}$ \\
Gasan & 312.5 & 26.66 & $3.880 \times 10^{-1}$ & $3.840 \times 10^{-2}$ \\
Mogpog & 376.7 & 13.56 & $7.215 \times 10^{-2}$ & $8.774 \times 10^{-2}$ \\
Torrijos & 318.9 & 29.24 & $7.632 \times 10^{-2}$ & $3.030 \times 10^{0}$ \\
Sta. Cruz & 415.7 & 19.74 & $1.230 \times 10^{0}$ & $2.387 \times 10^{0}$ \\
\hline
\end{tabular}

The potential ecological risk coefficients order of identified metals in crustaceans, tilapia, SW, and GW is summarized in Table 9. Only Zn had a potential ecological risk coefficient for Buenavista, though it recorded elevated concentrations for Fe and Mn. This was due to the absence of the standard pre-industrial reference level. The municipality of Sta. Cruz recorded PER order for $\mathrm{SW}$ as $\mathrm{Cd}>\mathrm{Cu}>\mathrm{Zn}>\mathrm{Pb}>\mathrm{Cr}$. The collected GW samples had PER orders as follows: (a) Boac: $\mathrm{Cd}>\mathrm{Cu}>\mathrm{Cr}>\mathrm{Pb}>\mathrm{Zn}$, (b) Buenavista: 
$\mathrm{Cd}>\mathrm{Zn}>\mathrm{Cr}>\mathrm{Pb}>\mathrm{Cu}$, (c) Gasan: $\mathrm{Cd}>\mathrm{Cu}>\mathrm{Zn}>\mathrm{Cr}>\mathrm{Pb}$, (d) Mogpog: $\mathrm{Zn}>\mathrm{Cd}>\mathrm{Cu}>$ $\mathrm{Pb}>\mathrm{Cr}$, (e) Torrijos: $\mathrm{Cd}>\mathrm{Zn}>\mathrm{Cu}>\mathrm{Pb}>\mathrm{Cr}$ and (f) Sta. Cruz: $\mathrm{Cd}>\mathrm{Cu}>\mathrm{Zn}>\mathrm{Pb}>\mathrm{Cr}$.

Table 9. Trend of potential ecological risk coefficient in crustaceans, tilapia, SW, and GW.

\begin{tabular}{|c|c|c|c|c|}
\hline \multirow{2}{*}{ Location } & \multicolumn{4}{|c|}{ Samples } \\
\hline & Crustaceans & Tilapia & SW & GW \\
\hline Boac & $\mathrm{Cu}>\mathrm{Zn}>\mathrm{Cr}$ & $\mathrm{Zn}>\mathrm{Cu}>\mathrm{Cr}$ & $\mathrm{Cd}>\mathrm{Cu}>\mathrm{Pb}>\mathrm{Cr}>\mathrm{Zn}$ & $\mathrm{Cd}>\mathrm{Cu}>\mathrm{Cr}>\mathrm{Pb}>\mathrm{Zn}$ \\
\hline Buenavista & $\mathrm{Cu}>\mathrm{Zn}>\mathrm{Cr}$ & $\mathrm{Zn}>\mathrm{Cu}>\mathrm{Cr}$ & $\mathrm{Zn}$ & $\mathrm{Cd}>\mathrm{Zn}>\mathrm{Cr}>\mathrm{Pb}>\mathrm{Cu}$ \\
\hline Gasan & $\mathrm{Cu}>\mathrm{Zn}>\mathrm{Cr}$ & $\mathrm{Cu}>\mathrm{Zn}>\mathrm{Cr}$ & $\mathrm{Cd}>\mathrm{Cu}>\mathrm{Pb}>\mathrm{Zn}>\mathrm{Cr}$ & $\mathrm{Cd}>\mathrm{Cu}>\mathrm{Zn}>\mathrm{Cr}>\mathrm{Pb}$ \\
\hline Mogpog & $\mathrm{Cu}>\mathrm{Zn}>\mathrm{Cr}$ & $\mathrm{Zn}>\mathrm{Cu}>\mathrm{Cr}$ & $\mathrm{Cu}>\mathrm{Zn}>\mathrm{Pb}$ & $\mathrm{Zn}>\mathrm{Cd}>\mathrm{Cu}>\mathrm{Pb}>\mathrm{Cr}$ \\
\hline Torrijos & $\mathrm{Cu}>\mathrm{Zn}>\mathrm{Cr}$ & $\mathrm{Zn}>\mathrm{Cu}>\mathrm{Cr}$ & $\mathrm{Cd}>\mathrm{Cu}>\mathrm{Pb}>\mathrm{Zn}>\mathrm{Cr}$ & $\mathrm{Cd}>\mathrm{Zn}>\mathrm{Cu}>\mathrm{Pb}>\mathrm{Cr}$ \\
\hline Sta. Cruz & $\mathrm{Cu}>\mathrm{Zn}>\mathrm{Cr}$ & $\mathrm{Zn}>\mathrm{Cu}>\mathrm{Cr}$ & $\mathrm{Cd}>\mathrm{Cu}>\mathrm{Zn}>\mathrm{Pb}>\mathrm{Cr}$ & $\mathrm{Cd}>\mathrm{Cu}>\mathrm{Zn}>\mathrm{Pb}>\mathrm{Cr}$ \\
\hline
\end{tabular}

\subsection{Relationship between the Human Health and the Environment}

The calculated PERs were used as the environmental variables (synthetic gradients) for the CCA and results were displayed by an ordination diagram where the synthetic gradients are indicated by green lines and the calculated HHIs are illustrated by dots (Figure 6). The important variables were known by their correlations with the Canonical Axis 1 and Canonical Axis 2. The CCA revealed that the second canonical axis is negatively correlated with the PER of GW samples, while positively correlated with the PER of the crustaceans. These data denote that the HHI of crustaceans (HHI_C) were significantly affected by its PER. The CCA maximizes the predictive power of the synthetic gradients. The departed plots in Figure 6 of HHIs of the SW (HHI_SW) and GW (HHI_GW) illustrated that these two areas were not significantly affected. The total inertia of the CCA of $60.98 \%$ suggested that the HHIs could be predicted by the PERs and effect/s on the HHI were significant. Thus, the PERs associated with the crustaceans, tilapia, and water tell us the pattern of HHIs in the environment by the tilapia/curstacean and water samples.

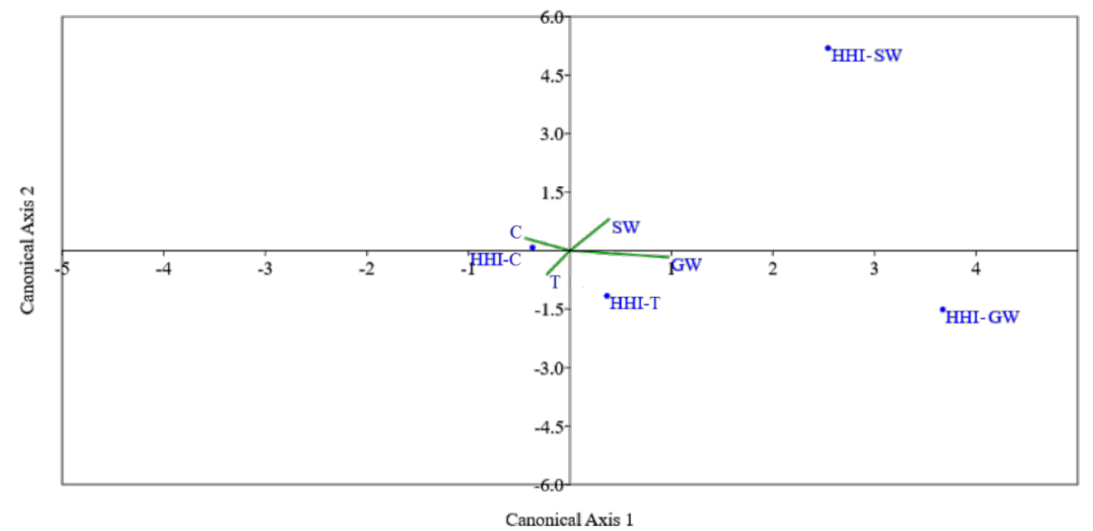

Figure 6. The canonical correspondence analysis (CCA) ordination of the ERI and HHI. Blue dots represent the HHI of crustaceans (HHI-CCA), tilapia (HHI-T), SW (HHI-SW), and GW (HHI-GW). The green lines represent the pERI of the crustaceans, tilapia, SW, and GW.

The Pearson correlation analyses were utlized to examine the relationships between the levels of heavy metals in crustaceans, tilapia, and water samples. It had two significant variables $(r, p)$ in the analysis. The $r$ tells us a relationship between variables. Whereas, the $p$ informs us if the relationship is statistically significant. The $p$-value $(p)$ denotes the correlation is significant if values ranged at the 0.01 and 0.05 bracket. Lower $p$-value denotes that correlation is statistically significant, whereas higher $\mathrm{p}$-value denotes the inverse. The $\mathrm{Cr}$ in tilapia was more strongly positively related to $\mathrm{Zn}, r(11)=0.726, p<0.01$, than to $\mathrm{Fe}$, $r(11)=0.711, p<0.01$. Likewise, Fe was strongly positively related to $\mathrm{Mn}, r(11)=0.700$, $p<0.01$. For the crustaceans, $\mathrm{Cu}$ was strongly positively related to $\mathrm{Zn}, r(11)=0.683, p<0.05$. 
On the other hand, Pearson correlation analysis for the relationships between $\mathrm{Cd}, \mathrm{Cr}, \mathrm{Cu}$, $\mathrm{Fe}, \mathrm{Pb}, \mathrm{Mn}, \mathrm{Ni}$, and $\mathrm{Zn}$ in the water samples showed significant positive correlation with other metals as enumerated in Tables 10 and 11 Positive significant correlations between these various metals suggested that these metals have similar origin, mutual dependence, and identical behavior during transport $[8,29,30]$.

Table 10. Correlation analysis of heavy metals in surface water samples using International Business Machine(IBM) Statistical Package for Social Sciences (SPSS), $N=62$.

\begin{tabular}{|c|c|c|c|c|c|c|c|c|}
\hline Metal & $\mathrm{Cd}$ & $\mathrm{Cr}$ & $\mathrm{Cu}$ & $\mathrm{Fe}$ & $\mathrm{Pb}$ & Mn & $\mathrm{Ni}$ & $\mathrm{Zn}$ \\
\hline $\mathrm{Cd}$ & & $0.968^{* *}$ & $0.452^{* *}$ & 0.243 & $0.940^{* *}$ & $0.251 *$ & $0.786^{* *}$ & $0.439 * *$ \\
\hline $\mathrm{Cr}$ & & & $0.368^{* *}$ & 0.241 & $0.896^{* *}$ & 0.211 & $0.705^{* *}$ & $0.358^{* *}$ \\
\hline $\mathrm{Cu}$ & & & & $0.489 * *$ & $0.386^{* *}$ & $0.712^{* *}$ & $0.725^{* *}$ & $0.911^{* *}$ \\
\hline $\mathrm{Fe}$ & & & & & 0.252 * & $0.680^{* *}$ & $0.410^{* *}$ & $0.613^{* *}$ \\
\hline $\mathrm{Pb}$ & & & & & & 0.212 & $0.721^{* *}$ & $0.378^{* *}$ \\
\hline $\mathrm{Mn}$ & & & & & & & 0.430 ** & 0.859 ** \\
\hline $\mathrm{Ni}$ & & & & & & & & $0.691^{* *}$ \\
\hline $\mathrm{Zn}$ & & & & & & & & \\
\hline
\end{tabular}

Table 11. Correlation analysis on heavy metals in groundwater samples using SPSS $(N=62)$.

\begin{tabular}{|c|c|c|c|c|c|c|c|c|}
\hline Metal & $\mathrm{Cd}$ & $\mathrm{Cr}$ & $\mathrm{Cu}$ & $\mathrm{Fe}$ & $\mathrm{Pb}$ & Mn & $\mathrm{Ni}$ & $\mathrm{Zn}$ \\
\hline $\mathrm{Cd}$ & & $0.840^{* *}$ & 0.169 & -0.021 & $0.959^{* *}$ & 0.074 & $0.959 * *$ & 0.056 \\
\hline $\mathrm{Cr}$ & & & -0.027 & 0.174 & $0.881^{* *}$ & 0.008 & $0.786^{* *}$ & 0.142 \\
\hline $\mathrm{Cu}$ & & & & 0.005 & 0.091 & $0.591^{* *}$ & $0.371^{* *}$ & 0.127 \\
\hline $\mathrm{Fe}$ & & & & & 0.204 & 0.056 & -0.014 & $0.858^{* *}$ \\
\hline $\mathrm{Pb}$ & & & & & & 0.042 & $0.908^{* *}$ & 0.244 \\
\hline $\mathrm{Mn}$ & & & & & & & 0.184 & 0.072 \\
\hline $\mathrm{Ni}$ & & & & & & & & 0.078 \\
\hline $\mathrm{Zn}$ & & & & & & & & \\
\hline
\end{tabular}

\section{Discussion}

Detected concentration of some transition and post-transition metals; e.g., $\mathrm{Cd}, \mathrm{Cr}$, $\mathrm{Cu}, \mathrm{Fe}, \mathrm{Mn}, \mathrm{Ni}, \mathrm{Pb}$, and $\mathrm{Zn}$, recorded elevated values. Elevated concentration was also observed in the work at Dhaka [31], India [32], Congo [33], and Malaysia [34]. The spatial distribution of various metals concentration in inland water as illustrated by Figure 2 and elaborated in Table 3 showed that the municipality of Sta. Cruz and Torrijos, respectively, had the highest metals concentration among the six municipalities. Concentration of $\mathrm{Mn}$ was the highest in all SW samples, and $\mathrm{Zn}$ in GW water samples across the island. The GW discharges to SW as part of the hydrological cycle. Hence, the SW and GW are interconnected with each other and possess a relationship during transport of contaminants. The affinity and fate of $\mathrm{Mn}$ and $\mathrm{Zn}$ during transport was associated with gram-positive bacteria [35] and gram-negative bacteria for some transition metals [36]. Though these studies were experimental and laboratory scale, it could be figured out the similar behavior of these microorganisms in the macro environment. Some mining activities used microorganisms such as Thiobacillus Ferrooxidans bacteria for metals extractions or recovery from ore [37-39]. The elevated metals concentrations in SW and GW were associated to continuous subsurface flow of toxicants in inland water. This could be attributed to the two abandoned open mine pits [8,9] located at the higher elevation (Maguilaguila and Mt. Tapian) of the island, its geological porous media written in Section 2.1, and the elevated concentration of these transition metals in soil [40]. These environmental conditions are similar to the areas described in Ghana [41] and Bolivia [42], which have mining activities [41,42] and areas in proximity to industrial zones [31-34]. Elevated Zn and Mn concentration in SW was also recorded in the mining-affected areas in Bolivia [42]. 
Recorded concentration of $\mathrm{Zn}$ in both crustaceans and tilapia, and $\mathrm{Cu}$ in crustaceans exceeded the maximum permissible limit. Also, concentration of $\mathrm{Cr}$ in both tilapia and crustaceans exceeded the USEPA [18] limit. Metals concentrations in crustaceans was higher than in tilapia. Similar results were recorded in Indonesia [43], India [44], Senegal [45], Brazil [46], and Nigeria [47]. However, the recorded Cr concentration of this study was higher than the recorded values of the countries written above. Likewise, the concentration of $\mathrm{Cu}$ in shrimps was way above the limit set by WHO [27] and USEPA [18]. These results of metals concentration in crustaceans and tilapia were attributed to various factors. These factors are temporal tropical climate, annual mean temperature of $27^{\circ} \mathrm{C}$ with no defined wet and dry season through the year, body size [48] (which affect uptake difference between crustaceans and fishes as illustrated in Figure 4), habitat, feeding nature, bioavailability, feeding efficiency [44], and availability of metals species. The metals concentration was compared with neighboring countries along the meridian (latitude), where the Philippines is located. The Cu concentration reported by India [6], Indonesia [43], Senegal [45], Brazil [46], and Singapore [49] was way below the recorded concentration values in this study. In the work of Giri and Singh [50] on the Subarnarekha River in India, the concentration range of metals in fish and shrimp (crustaceans) were lower than the concentration range of this study. Mn was not included in the scope of Giri and Singh [50]. This Subarnarekha river is also rich in minerals and hosts minerals-based industry with unplanned and unregulated mining activities [51]; hence, this condition was similar to the island of Marinduque in which presence of mining activities contribute to the elevated concentration of metals in water, freshwater crustaceans, and fish.

Long-term exposure to crustaceans, tilapia, and inland water in Marinduque may result to one cancer patient per 100,000 population, which according to USEPA [16] is acceptable. Crustaceans, tilapia, and inland water were only the three edible items in Marinduque considered in the calculation of cancer risk probability in this study. This means additional ingestion of other edibles with elevated metals concentration adds onto the health risks posed by crustaceans, tilapia, and water. This condition was also elaborated by the work of Anankumar et al. [48] and Orosun et al. [47], who showed that exposure to toxic and trace metals at higher concentrations will cause chronic health adverse effects to humans, including HIV prevalence [52], anemia [53], and mental health problems/cognitive impairment [54,55]. Further, ingestion of metals and metalloids in crops contribute to morbidity and/or mortality [55]. The highest cumulative PER areas based on inland water, crustaceans, and tilapia are the municipalities of Sta. Cruz, Torrijos, and Boac. The order of PER for GW and SW at Sta. Cruz were the same. This was attributed to the two abandoned open mine pits in Marinduque as this island sits on volcanic, igneous, and volcanic rocks [9]. Similar condition of exposure to mine tailings by the population in South Africa was elaborated by the work of Ngole-Jeme and Fantke [52]. Also, the positive correlation and affinity of transition and post-transition metals were attributed to a reducing environment such as deep abandoned open mine pit in which weathering is taking place-producing sulphides from acid rock drainage. These sulphides could carry metals during transport through porous media, which Marinduque has [9], such as Cd, Cr, $\mathrm{Ni}, \mathrm{Pb}$, and $\mathrm{Zn}$, as illustrated in Tables 3 and 4 and Figures 3 and 4 . This condition was also discussed by the Geological Survey of Sweden [30].

\section{Conclusions}

This study conducted sampling activities, laboratory analysis using ICP-OES, followed Hakanson Sedimentological Approach, employing CCA, IBM SPSS, Pearson correlation, and utilizing the GIS tool to provide information on the spatial distribution of metals concentration and potential ecological risks to the island province of Marinduque, Philippines. Inland water, crustaceans, and tilapia were samples used in the study. Eight metals $(\mathrm{Cd}, \mathrm{Cr}$, $\mathrm{Cu}, \mathrm{Fe}, \mathrm{Mn}, \mathrm{Ni}, \mathrm{Pb}$, and $\mathrm{Zn}$ ) were targeted in this study. Results showed that Mn concentration was highest in SW, while $\mathrm{Zn}$ was highest in GW among the other eight metals that were analyzed. The GW of the municipalities of Sta. Cruz and Torrijos recorded a larger area of 
elevated concentration. Also, the riverside barangays in Mogpog municipality had elevated concentration of $\mathrm{Cd}, \mathrm{Cr}, \mathrm{Fe}, \mathrm{Pb}$, and $\mathrm{Mn}$ in $\mathrm{GW}$. The $\mathrm{Mn}$ had the highest concentration in $\mathrm{SW}$. The $\mathrm{Zn}$ concentration was highest in GW. This condition (i.e., highest concentration of $\mathrm{Mn}$ in SW and $\mathrm{Zn}$ in GW) was across all six municipalities of the island province. The municipality of Sta. Cruz recorded the highest concentration of metals among the six municipalities of Marinduque. Elevated concentration of $\mathrm{Zn}$ was detected in both crustaceans and tilapia. Elevated $\mathrm{Cu}$ was detected in crustaceans only. The crustaceans recorded higher concentrations of the eight metals compared to tilapia. The municipality of Torrijos and Sta. Cruz recorded the highest pERI for GW among the six municipalities. The O. niloticus and C. striata had low pERI while considerable for Macrobrchium species. However, there is high potential health risk if consumed. The likelihood of the receptor to develop or acquire cancer due to exposure to the abovementioned transition metals was one case per 100,000 population $\left(10^{-5}\right)$. This was considered acceptable lifetime carcinogenic risk. Further, the result of the statistical analysis showed that the metals concentration in SW and GW suggested to have similar source/s, mutual dependence, and identical behavior during transport. The data in this study are useful in the improvement of existing policies and programs, and creating strategies for the sustainable development of the island province.

Author Contributions: Conceptualization, D.B.S.; methodology, C.J.M.A. and D.B.S.; software, C.J.M.A.; validation, C.J.M.A., D.R.M. and R.N.; formal analysis, C.J.M.A. and E.C.; investigation, C.J.M.A., D.R.M., R.N. and D.B.S.; resources, D.B.S.; data curation, C.J.M.A. and R.N.; writingoriginal draft preparation, C.J.M.A.; writing-review and editing, D.B.S., D.R.M., and E.C.; visualization, C.J.M.A.; supervision, D.B.S. and D.R.M.; project administration, D.B.S.; funding acquisition, D.B.S. All authors have read and agreed to the published version of the manuscript.

Funding: This research was funded by the Philippine Council for Health Research and Development of the Department of Science and Technology, Philippines.

Institutional Review Board Statement: Not Applicable.

Informed Consent Statement: Not Applicable.

Data Availability Statement: All data are contained in the manuscript.

Acknowledgments: This is to acknowledge the support "in kind" of Mapua University, Manila Philippines, the Marinduque State College, Boac, Marinduque, Philippines, and the local government units of its cooperation.

Conflicts of Interest: The authors declare no conflict of interest.

\section{References}

1. Marges, M.; Su, G.S.; Ragragio, E. Assessing heavy metals in the waters and soils of Calancan bay, Marinduque island, Philippines. J. Appl. Sci. Environ. San. 2011, 6, 45-49.

2. Lindon, J.G.; Canare, T.A.; Mendoza, R.U. Corporate and public governance in mining: Lessons from the Marcopper mine disaster in Marinduque, Philippines. Asian J. Bus. Ethics 2014. [CrossRef]

3. Bennagen, M.E. Estimation of environmental damages from mining pollution: The Marinduque island mining accident. In EEPSEA Research Report rr1998111; Economy and Environment Program for Southeast Asia (EEPSEA): Los Baños, Laguna, Philippines, 1998.

4. Plumlee, G.S.; Morton, R.A.; Boyle, T.P.; Medlin, J.H.; Centeno, J.A. An Overview of Mining-Related Environmental and Human Health Issues, Marinduque Island, Philippines: Observation from Joint U.S. Geological Survey-Armed Forces Institute of Pathology Reconnaissance Field Evaluation, 12-19 May 2000; USGS Science for a Changing World: Denver, CO, USA, 2000. [CrossRef]

5. Ayres, R.U.; Ayres, L.W.; Råde, I. The Life Cycle of Copper, Its Co-Products and Byproducts. Eco-Effic. Ind. Sci 2003. [CrossRef]

6. Arulkumar, A.; Paramasivam, S.; Rajaram, R. Toxic heavy metals in commercially important food fishes collected from Palk Bay, Southeastern India. Mar. Pollut. Bull. 2017, 119, 454-459. [CrossRef]

7. Baby, J.; Raj, J.; Biby, E.; Sankarganesh, P.; Jeevitha, M.; Ajisha, S.; Rajan, S. Toxic effect of heavy metals on aquatic environment. Int. J. Biol. Chem. Sci 2011. [CrossRef]

8. Senoro, D.B.; De Jesus, K.L.M.; Yanuaria, C.A.; Bonifacio, P.B.; Manuel, M.T.; Wang, B.N.; Kao, C.C.; Wu, T.N.; Ney, F.P.; Natal, P. Rapid site assessment in a small island of the Philippines contaminated with mine tailings using ground and areal technique: The environmental quality after twenty years. Iop Conf. Ser. Earth Environ. Sci. 2019, 351, 012022. [CrossRef] 
9. David, C. Heavy metal concentrations in marine sediments impacted by a mine-tailings spill, Marinduque Island, Philippines. Environ. Geol. 2002, 42, 955-965. [CrossRef]

10. Coumans, C. Placer dome Case Study: Marcopper Mines Dispo-Paulo E. Guimarães Juan D. Pérez Cebada XXVII; Mining Watch: Ottawa, ON, Canada, 2002.

11. Ragragio, E.; Belleza, C.; Narcisio, M.; Su, G. Assessment of micronucleus frequency in exfoliated buccal epithelial cells among fisher folks exposed to mine tailings in Marinduque Island, Philippines. Asian Pac. J. Trop. Med. 2010, 3, 315-317. [CrossRef]

12. Holden, W.N. Mining and typhoons: Large-scale mining and typhoon vulnerability in the Philippines. Extr. Ind. Soc. 2015, 2, 45-61. [CrossRef]

13. Helen, D.; Vaithynathan, C.; Ramalingom, P.A. Assessment of heavy metal contamination and sediment quality of Thengapattinam estuary in Kanyakumari District. Int. J. Chem. Phys. Sci. 2006, 5, 8-17.

14. Kikuchi, T.; Furuichi, T.; Hai, H.T.; Tanaka, S. Assessment of heavy metal pollution in river water of Hanoi, Vietnam using mutlivariate analyses. Bull. Environ. Contam. Toxicol. 2009, 83, 575-582. [CrossRef]

15. Chaiyara, R.; Ngoendee, M.; Kruatrachue, M. Accumulation of $\mathrm{Cd}, \mathrm{Cu}, \mathrm{Pb}$, and $\mathrm{Zn}$ in water, sediments, and mangrove crabs (Sesarma mederi) in the upper Gulf of Thailand. Sci. Asia 2013, 39, 3763-3783. [CrossRef]

16. Huang, S.H.; Wang, Y.L.; Li, S.H.; Chien, L.C.; Chang, T.C.; Hseu, Z.Y.; His, H.C. Environmental and health risks of heavy metals in farmlands soils of drinking water protection areas and a contaminated paddy field in Taiwan. Sustainability 2019, 11, 5166. [CrossRef]

17. Håkanson, L. An ecological risk index for aquatic pollution control a sedimentological approach. Water Res. 1980, 14, 975-1001. [CrossRef]

18. U.S. EPA (United States Environmental Protection Agency). Guidance for Assessing Chemical Contaminant Data for Use in Fish AdvisoriesRisk Assessment and Fish Consumption Limits, 3rd ed;; Office of Water: Washington, DC, USA, 2000; Volume 2, EPA 823-B-00-008.

19. U.S. EPA (United States Environmental Protection Agency). Edition of the Drinking Water Standards and Health Advisories; Office of Water: Washington, DC, USA, 2012; EPA 822-S-12-001.

20. Milenkovic, B.; Stajic, J.M.; Stojic, N.; Pucarevic, M.; Strbac, S. Evaluation of heavy metals and radionuclides in fish and seafood products. Chemosphere 2019. [CrossRef]

21. Saha, N.; Mollah, M.Z.I.; Alam, M.F.; Safiur Rahman, M. Seasonal investigation of heavy metals in marine fishes captured from Bay of Bengal and the implications for human health risk assessment. Food Control 2016. [CrossRef]

22. Miri, M.; Akbari, E.; Amrane, A.; Jafari, S.J.; Eslami, H.; Hoseinzadeh, E.; Zarrabi, M.; Salimi, J.; Sayyad-Arbari, M.; Taghavi, M. Health risk assessment of heavy metal intake due to fish consumption in the Sistan region, Iran. Environ. Monit. Assess 2017. [CrossRef]

23. Kortei, N.K.; Heymann, M.E.; Essuman, E.K.; Kpodo, F.M.; Akonor, P.T.; Lokpo, S.Y.; Boadi, N.O.; Ayim-Akonor, M.; Tettey, C. Health risk assessment and levels of toxic metals in fishes (Oreochromis noliticus and Clarias anguillaris) from Ankobrah and Pra basins: Impact of illegal mining activities on food safety. Toxicol. Rep. 2020. [CrossRef] [PubMed]

24. WHO. Guidelines for Drinking Water Quality Recommendations, 2nd ed.; World Health Organization: Geneva, Switzerland, 1993; Volume 1.

25. PNSDW. Summary of Standard Values and Methods of Analysis for Inorganic Chemical Parameters of Drinking Water. In Philippine National Standards for Drinking Water of 2017; Department of Health (DOH) Administrative Order No. 2017-0010, Table A-2; DOH: Manila, Philippines, 2017.

26. FAO (Food and Agricultural Organization). Compilation of Legal Limits for Hazardous Substance in Fsh and Fishery Products; Food and Agricultural Organization: Rome, Italy, 1983.

27. WHO. Heavy Metals Environmental Aspects. Environmental Health Criteria; World Health Organization: Geneva, Switzerland, 1989.

28. EC. Commission Regulation. No. 488/2014 of 12 May 2014 Amending Regulation (EC) no. 1881/2006 as Regards Maximum Levels of Cadmium in Foodstuffs; European Commission: Brussels, Belgium, 2014.

29. Håkanson, L.; Jansson, M. Principles of Lake Sedimentology; Springer: Berlin/Heidelberg, Germany, 1983.

30. SGU. Geointro Geological Survey of Sweden. 2020. Available online: https://www.sgu.se/en/geointro/about-geointro/ (accessed on 20 September 2020).

31. Rahman, M.S.; Saha, N.; Molla, A.H. Potential ecological risk assessment of heavy metal contamination in sediment and water body around Dhaka export processing zone, Bangladesh. Environ. Earth Sci. 2014. [CrossRef]

32. Somagouni, S.G.; Govil, P.K. Distribution of heavy metals in surface water of Ranipet industrial area in Tamil Nadu, India. Environ. Monit Assess 2008, 136, 197-207.

33. Atibu, E.K.; Devarajan, N.; Thevenon, F.; Mwanamoki, P.M.; Tshibanda, J.B.; Mpiana, P.T.; Prabakar, K.; Mubedi, J.I.; Wildi, W.; Poté, J. Concentration of metals in surface water and sediment of Luilu and Musonoie Rivers, Kolwezi-Katanga, Democratic Republic of Congo. J. Appl. Geochem. 2013, 39, 26-32. [CrossRef]

34. Law, A.T.; Singh, A. Distribution of manganese, iron, copper, lead and zinc in water and sediment of Kelang estuary. Pertanika 1986, 9, 209-217.

35. Claverys, J.P. A new family of high-affinity ABC manganese and zinc permeases. Res. Microbiol. 2001, 152, 231-243. [CrossRef]

36. Porcheron, G.; Garenauz, A.; Proulx, J.; Sabri, M.; Dozois, C.M. Iron, copper, zinc and manganese transport and regulation in pathogenic Enterobacteria: Correlations between strains, site of infection and the relative importance of the different metal transport systems for virulence. Front. Cell Infect. Microbiol. 2013, 3, 90. [CrossRef] 
37. Maluckov, B.S. The Catalytic Role of Acidithiobacillus ferooxidans metals extraction from mining-Metallurgical resource. Biodivers. Int. J. 2017, 1, 00017. [CrossRef]

38. Wang, J.; Qin, W.Q.; Zhang, Y.S.; Yang, C. Bacterial leaching of chalcopyrite and bornite with native bioleaching microorganism. Trans. Nonferrous Met. Soc. China 2008, 18, 1468-1472. [CrossRef]

39. Baba, A.A.; Adekola, F.A.; Atata, R.F.; Ahmed, R.N.; Panda, S. Bioleaching of $\mathrm{Zn}(\mathrm{II})$ and $\mathrm{Pb}$ (II) from Nigerian sphalerite and galena ores by mixed culture of acidophilic bacteria. Trans. Nonferrous Met. Soc. China 2011, 2, 2535-2541. [CrossRef]

40. Senoro, D.B.; Bonifacio, P.B.; Mascarenas, D.R.; Tabelin, C.B.; Ney, F.P.; Lamac, M.R.L.; Tan, F.J. Spatial distribution of agricultural yields with elevated metal concentration on the island exposed to acid mine drainage. J. Degaded. Min. Lands Manag. 2021, 8, $2551-2558$. [CrossRef]

41. Koranteng-Addo, E.J.; Owusu-Ansah, E.; Boamponsen, L.K.; Bentum, J.K.; Arthur, S. Levels of zinc, copper, iron and manganese in soils of abandoned mine pits around the Tarkwa gold mining area of Ghana. Adv. Appl. Sci. Res. 2011, 2, $280-288$.

42. French, M.; Alem, N.; Edwards, S.J.; Coariti, E.B.; Cauthin, H.; Hudson-Edwards, K.A.; Luyckx, K.; Quintanilla, J.; Miranda, O.S. Community exposure and vulnerability to water quality and availability: A case study in the mining-affected Pazna Municipality, Lake Poopo Basin, Bolivian Altiplano. Environ. Manag. 2017, 60, 555-573. [CrossRef]

43. Candra, Y.A.; Syaifullah, M.; Irawan, B.; Putranto, T.W.C.; Hidayati, D.; Soegianto, A. Concentrations of metals in mantis shrimp Harpiosquilla harpax (de Haan, 1844) collected from the eastern region of Java Sea Indonesia, and potential risks to human health. Reg. Stud. Mar. Sci. 2019, 26, 100507. [CrossRef]

44. Hossain, M.S.; Khan, Y.S.A. Trace metal in penaeid shrimp and spiny lobster from the Bay of Bengal. Sci. Asia 2001, 27, 165-168. [CrossRef]

45. Diop, M.; Howsam, M.; Diop, C.; Goossens, J.F.; Diouf, A.; Amara, R. Assessment of trace element contamination and bioaccumulation in algae (Ulva lactuca), mussels (Perna perna), shrimp (Penaeus kerathurus) and fish (Mugil cephalus, Saratherondon melanotheron) along the Senegalese coast. Mar. Pollut Bull. 2015. [CrossRef]

46. Abuquerque, F.E.A.; Minervino, A.H.H.; Miranda, M.; Herrero-Latorre, C.; Júnior, R.A.B.; Oliveira, F.L.C.; Dias, S.R.; Ortalani, E.L.; López-Alonso, M. Toxic and essential trace element concentrations in the freshwater shrimp Macrobrachium amazonicum in the Lower. Amazon, Brazil. J. Food Compost. Anal 2019. [CrossRef]

47. Orosun, M.M.; Tchokossa, P.; Orosun, R.O.; Akinyose, F.C.; Ige, S.O.; Oduh, V.O. Determination of selected heavy metals and human health risk assessment in fishes from Kiri Dam and River Gongola, Northeaaaastern Nigeria. J. Phys. Chem. Biophys. 2016, 6, 2161-0398. [CrossRef]

48. Anandkumar, A.; Nagarajan, R.; Prabakaran, K.; Bing, C.H.; Rajaram, R. Human health risk assessment and bioaccumulation of trace metals in fish species collected from the Miri coast, Sarawak, Borneo. Mar. Pollut. Bull. 2018, 133, 655-663. [CrossRef]

49. Bayen, S.; Koroleva, E.; Lee, H.K.; Obbard, J.P. Persistent organic pollutants and heavy metals in typical seafoods consumed in Singapore. J. Toxicol. Enviro. Health Part A 2005, 68, 151-166. [CrossRef]

50. Giri, S.; Singh, A.K. Human health risk and ecological risk assessment of metals in fishes, shrimps and sediments from a tropical river. Int. J. Environ. Sci. Technol. 2014, 12, 2349-2362. [CrossRef]

51. Singh, A.K.; Giri, S. Subanarekha River: The Gold Streak of India. In The Indian Rivers, Springer Hydrogeology; Springer Nature Singapore Pte Ltd.: Singapore, 2018. [CrossRef]

52. Ngole-Jeme, V.M.; Fantke, P. Ecological and human health risks associated with abandoned tailings contaminated soil. PLoS ONE 2017, 12, e0172517. [CrossRef]

53. Mandeng, E.P.B.; Bidjeck, L.M.B.; Bessa, A.Z.E.; Ntomb, Y.D.; Wadjou, J.W.; Doumo, E.P.E.; Dieudonne, L.B. Contamination and risk assessment of heavy metals, and uranium of sediments in two watersheds in Abiete-Toko gold district, Southern Caroon. Heliyon 2019, 5, e02591. [CrossRef]

54. Iqbal, G.; Zada, W.; Mannan, A.; Ahmed, T. Elevated heavy metals levels in cognitively impaired patients from Pakistan. Envronmental Toxicol. Pharmacol. 2018, 60, 100-109. [CrossRef]

55. Rai, P.K.; Lee, S.S.; Zhang, M.; Tsang, Y.F.; Kim, K.H. Heavy metals in food crops: Health risks, fate, mechanisms, and management. Environ. Int. 2019, 125, 365-385. [CrossRef] 